\title{
PHYSICAL FITNESS RESULTS OF SOLDIERS OF DIFFERENT AGE GROUPS IN THE LAND FORCE OF THE LITHUANIAN PROFESSIONAL ARMED FORCES IN 2010-2011
}

\author{
Aurelijus Savonis ${ }^{1,2}$, Algirdas Čepulènas ${ }^{2}$ \\ Division General Stasys Raštikis Lithuanian Armed Forces School Physical Training Center ${ }^{l}$, \\ Kaunas, Lithuania \\ Lithuanian Sports University', Kaunas, Lithuania
}

\begin{abstract}
Research background and hypothesis. Since 2009 Lithuanian Armed Forces have been formed from soldiers in professional service. Research on military physical fitness in the Lithuanian Armed Forces is scarce. This research aims at verifying the hypothesis that physical fitness indices of soldiers in the Land Force of the professional Lithuanian Armed Forces match the established physical fitness normative requirements.

Research aim was to study peculiarities of changes in physical fitness results of soldiers of different age groups in the Land Force of the Lithuanian Professional Armed Forces in the period of two years.

Research methods: literature review, physical fitness testing, statistical analysis of physical fitness indices. Results in each physical fitness exercise were evaluated in points according to physical fitness normative scales. The sum of points for all exercises was the final physical fitness evaluation result.

Research results. In the period of half a year, from spring to autumn and from autumn to spring, physical fitness of soldiers in all age groups changed only slightly $(p>0.05)$. During the period of one year, from testing in spring till testing in spring of the following year, physical fitness indices improved $(p<0.05)$. Even $2-4 \%$ of soldiers failed physical fitness normative tests.

Discussion and conclusions. Physical fitness indices of different exercise for soldiers in the Land Force of the professional Lithuanian Armed Forces were higher than the established minimal normative requirements. The highest physical fitness indices were achieved in the age groups of $18-21,22-26,27-31$ and 30-36 years, however, the differences between the age groups were insignificant.

In perspective, while developing military physical fitness control system, the evaluation of physical fitness should be differentiated according to the normative scale which includes such evaluations as "excellent", "good", "fair".
\end{abstract}

Keywords: Land Force, physical fitness, testing, physical fitness test, age group, points.

\section{INTRODUCTION}

$\mathrm{M}$ ilitary physical training is a very important structural part of the military training (Greičius et al., 1998; Lietuvos gynybos politikos baltoji knyga, 2002; Sokołovski, 2002; Gorski, 2007; Witkovski, Stefaniak, 2007). After Lithuania entered NATO, physical fitness of soldiers in the Lithuanian Armed Forces has to meet the requirements for soldiers in all NATO
Armed Forces (Kariu fizinio rengimo metodinès rekomendacijos, 2003). In NATO Armed Forces, physical training and physical fitness of soldiers receive much attention; self-training in physical activity is emphasized (Sokolovski, 2002; Dyrstad et al., 2006; Janowski et al., 2009; Kruszkovski et al., 2011). The problem of physical fitness in professional armed forces is a research object for 
many researchers (Faff et al., 2002; Dyrstad et al., 2006; Młynarczyk et al., 2007; Dybińska, 2009, 2011; Dobosz, Świercz, 2011).

Since 2009 Lithuanian Armed Forces have been formed from soldiers in professional service. Irrespective of the military rank, age limits and the positions, all soldiers need optimal levels of physical fitness according to their age group. Research on military physical fitness in the Lithuanian Armed Forces is scarce (Savonis, Čepulėnas, 2011, 2012). Physical training systems in the Lithuanian Military Academy as well as changes in physical fitness of cadets during their studies have been studied by other researchers (Radžiukynas, 1999; Radžiukynas, Endrijaitis, 2003; Streckis et al., 2004; Sipavičius et al., 2008).

Changes in physical fitness of compulsory military service conscripts have been studied by A. Vilkas et al. (1994), D. Radžiukynas et al. (2006), E. Trinkūnas (2009), and V. Ivaškienè (2010). Professional armed forces include soldiers of different age, and reference standards of physical fitness are differentiated according to age. Land Force comprises the majority of the Lithuanian Professional Armed Forces.

The aim of the current research was to study peculiarities of changes in physical fitness results of soldiers of different age groups in the Land Force of the Lithuanian Professional Armed Forces in the period of two years.

\section{RESEARCH METHODS}

Research sample included the professional service land force soldiers of eight age groups: $18-21,22-26,27-31,32-36,37-41,42-46,47-61$ and 52-56 years of age. The data of the research participants who passed the standard physical fitness tests are provided in Table 1 and Table 2. The tests were carried out four times - in 2010 and 2011, in spring (April) and autumn (October). Research timetable was approved by the order of the Land Force Commander.

Research participants were soldiers of all military ranks - from enlisted soldiers to Generals. During each study the soldiers performed Army Physical Fitness Test (APFT) which was prepared following the recommendations of the physical fitness and physical training test used in the USA Armed Forces (Physical Fitness Training FM21-20). This test was approved by the Order No. V-980, October 4, 2007, of the Lithuanian Minister of National Defence.
The test included the following physical exercises:

- Arm strength endurance - bending and reaching arms in a lying position for $2 \mathrm{~min}$;

- Abdominal muscle strength endurance - sit ups for $2 \mathrm{~min}$;

- Aerobic endurance - $3000 \mathrm{~m}$ run.

The result of each exercise was assessed in points according to Military Physical Fitness Reference Scales (Savonis, Čepulènas, 2011, 2012). In each age group, the assessment in points for each exercise was different. Minimal results of a control exercise had to reach 60 points (this was the norm for a pass). The highest assessment for a physical exercise was 100 points. Results between 60 and 100 points were evaluated in points according to a reference scale of each age group. The sum of points for all exercises comprised the total APFT result. In each exercise the soldier had to get no less than 60 points according to a reference scale of his age group.

Statistical analysis of the research data was carried out using Microsoft Excel and Statistica -8 programmes. The following parameters were calculated: arithmetic mean (x), standard deviation $( \pm \mathrm{SD})$, Student's $t$ test and index $\mathrm{p}$ for statistical significance. The level of significance was set at $95 \%$, when $\mathrm{p}<0.05$.

\section{RESEARCH RESULTS}

Research results (Tables 1 and 2) showed that the majority of soldiers in the Land Force of the Lithuanian Armed Forces were 22-26, 27-31 and 32-36 years old, 500 soldiers in each age group on average. The age groups of 37-41 and 52-56 years had fewer soldiers. Very few soldiers were in the groups of 47-51 and 52-56 years of age. This can be explained by the fact that for military service this age is the age of retirement. We should note that rather few soldiers were in the group of 18-21 years of age. Young men of this age had finished schools and many of them studied in colleges and universities. At present they are not called for mandatory military service. Few of them choose professional military service. Tables 1 and 2 contain the results of all soldiers who have passed all APFT tests.

The indices of arm strength endurance (bending and reaching arms in a lying position for $2 \mathrm{~min}$ ) for soldiers in all age groups (Tables 1 and 2) did not change significantly $(\mathrm{p}>0.05)$ between the two tests in spring (I) and autumn (II) in 2010. In the course of one year, from spring (I) 2010 till spring 
(III) 2011, the indices of arm strength endurance improved significantly $(\mathrm{p}<0.05)$ in the age groups of $18-21,22-26,27-31$ and $32-36$ years. In the age groups of $37-41,42-46,47-51$ and $52-56$ years, changes in these indices were insignificant $(p>0.05)$. The highest relative evaluations in points for bending and reaching arms (in regard to the age norms) were given to soldiers in the groups of 18-21, 22-26, 27-31, 32-36 and 37-41years of age. In all age groups the evaluation of this exercise in points was higher than 60 - the minimal norm.
Abdominal muscle strength endurance indices (in sit ups for $2 \mathrm{~min}$ ) improved significantly $(p<0.05)$ in the period of one year (from spring (I) 2010 till spring (III) 2011) in the age groups of 18 21, 22-26, 27-31 and 32-36 years (Table 1). The greatest relative evaluations in points for exercises were received by soldiers in the group of 18-21 years: from $79.58 \pm 13.34$ to $82.79 \pm 13.27$ points. The lowest evaluations were obtained by 47-51and 52-56 year-old soldiers. All soldiers except for the group of 47-51 years improved their results in

Table 1. Changes in physical fitness indices of soldiers in the Land Force of the Lithuanian Armed Forces in different age groups (from 18 to 36 years of age) in the periods of 2010-2011 $(\bar{x} \pm \mathrm{SD})$

\begin{tabular}{|c|c|c|c|c|c|c|c|c|}
\hline \multirow{2}{*}{$\begin{array}{l}\text { Age } \\
\text { group }\end{array}$} & \multirow{2}{*}{ Phase } & \multirow{2}{*}{$\mathbf{n}$} & \multicolumn{2}{|c|}{$\begin{array}{c}\text { Hand bending and stretch in } \\
\text { lying position } 2 \mathrm{~min}\end{array}$} & \multicolumn{2}{|c|}{ Sit-ups 2 min } & \multicolumn{2}{|c|}{ Run 3000 m } \\
\hline & & & Result, times & Points & Result, times & Result, times & Points & Result, times \\
\hline \multirow{4}{*}{$18-21$} & 1 & 99 & $56.93 \pm 10.28$ & $79.96 \pm 12.84$ & $65.66 \pm 9.05$ & $79.58 \pm 13.34$ & $787.91 \pm 53.15$ & $84.51 \pm 11.09$ \\
\hline & 2 & 132 & $59.92 \pm 11.21$ & $83.14 \pm 12.68$ & $67.47 \pm 9.78$ & $81.85 \pm 13.50$ & $789.18 \pm 52.89$ & $84.24 \pm 10.97$ \\
\hline & 3 & 137 & $62.23 \pm 11.29$ & $86.10 \pm 13.10$ & $67.89 \pm 9.37$ & $82.79 \pm 13.21$ & $781.81 \pm 56.95$ & $85.33 \pm 11.08$ \\
\hline & 4 & 167 & $60.39 \pm 10.02$ & $84.66 \pm 12.21$ & $67.81 \pm 9.60$ & $82.20 \pm 12.61$ & $781.69 \pm 58.26$ & $86.01 \pm 11.41$ \\
\hline \multirow{4}{*}{$\mathrm{p}$} & \multicolumn{2}{|c|}{$1-2$} & $<0.05$ & $>0.05$ & $>0.05$ & $>0.05$ & $>0.05$ & $>0.05$ \\
\hline & \multicolumn{2}{|c|}{$2-3$} & $>0.05$ & $>0.05$ & $>0.05$ & $>0.05$ & $>0.05$ & $>0.05$ \\
\hline & \multicolumn{2}{|c|}{$1-3$} & $<0.001$ & $<0.001$ & $>0.05$ & $<0.01$ & $>0.05$ & $>0.05$ \\
\hline & \multicolumn{2}{|c|}{$2-4$} & $>0.05$ & $>0.05$ & $>0.05$ & $>0.05$ & $>0.05$ & $>0.05$ \\
\hline \multirow{4}{*}{$22-26$} & 1 & 500 & $58.05 \pm 12.82$ & $79.92 \pm 13.54$ & $63.89 \pm 10.59$ & $78.08 \pm 13.28$ & $807.34 \pm 66.64$ & $83.83 \pm 11.26$ \\
\hline & 2 & 435 & $58.39 \pm 12.01$ & $80.54 \pm 13.00$ & $64.32 \pm 10.22$ & $78.60 \pm 12.70$ & $810.13 \pm 64.50$ & $83.59 \pm 11.30$ \\
\hline & 3 & 474 & $61.23 \pm 12.22$ & $83.49 \pm 12.69$ & $65.46 \pm 10.35$ & $80.01 \pm 12.56$ & $806.92 \pm 65.50$ & $84.07 \pm 11.33$ \\
\hline & 4 & 486 & $58.33 \pm 12.27$ & $80.37 \pm 12.55$ & $64.27 \pm 10.15$ & $78.54 \pm 12.51$ & $817.42 \pm 66.00$ & $82.41 \pm 11.30$ \\
\hline \multirow{4}{*}{$\mathrm{p}$} & \multicolumn{2}{|c|}{$1-2$} & $>0.05$ & $>0.05$ & $>0.05$ & $>0.05$ & $>0.05$ & $>0.05$ \\
\hline & \multicolumn{2}{|c|}{$2-3$} & $<0.001$ & $<0.001$ & $>0.05$ & $>0.05$ & $>0.05$ & $>0.05$ \\
\hline & \multicolumn{2}{|c|}{$1-3$} & $<0.001$ & $<0.001$ & $<0.025$ & $<0.025$ & $>0.05$ & $>0.05$ \\
\hline & \multicolumn{2}{|c|}{$2-4$} & $>0.05$ & $>0.05$ & $>0.05$ & $>0.05$ & $>0.05$ & $>0.15$ \\
\hline \multirow{4}{*}{$27-31$} & 1 & 566 & $56.71 \pm 13.05$ & $78.32 \pm 13.03$ & $60.72 \pm 12.09$ & $76.64 \pm 12.46$ & $845.88 \pm 68.24$ & $80.87 \pm 11.62$ \\
\hline & 2 & 509 & $56.50 \pm 13.03$ & $78.05 \pm 12.81$ & $60.58 \pm 11.58$ & $76.52 \pm 11.98$ & $841.96 \pm 71.12$ & $81.50 \pm 11.82$ \\
\hline & 3 & 530 & $59.06 \pm 12.93$ & $80.71 \pm 12.87$ & $62.39 \pm 11.75$ & $78.47 \pm 12.15$ & $833.74 \pm 69.65$ & $82.79 \pm 11.53$ \\
\hline & 4 & 509 & $57.76 \pm 12.51$ & $79.47 \pm 12.39$ & $62.16 \pm 11.37$ & $78.36 \pm 11.98$ & $839.32 \pm 70.67$ & $81.97 \pm 11.41$ \\
\hline \multirow{4}{*}{$\mathrm{p}$} & \multicolumn{2}{|c|}{$1-2$} & $>0.05$ & $>0.05$ & $>0.05$ & $>0.05$ & $>0.05$ & $>0.05$ \\
\hline & \multicolumn{2}{|c|}{$2-3$} & $<0.005$ & $<0.001$ & $<0.05$ & $<0.01$ & $>0.05$ & $>0.05$ \\
\hline & \multicolumn{2}{|c|}{$1-3$} & $<0.005$ & $<0.005$ & $<0.025$ & $<0.005$ & $<0.01$ & $<0.005$ \\
\hline & \multicolumn{2}{|c|}{$2-4$} & $>0.05$ & $>0.05$ & $<0.05$ & $<0.025$ & $>0.05$ & $>0.05$ \\
\hline \multirow{4}{*}{$32-36$} & 1 & 561 & $52.21 \pm 12.83$ & $76.88 \pm 12.57$ & $54.39 \pm 11.62$ & $74.16 \pm 12.80$ & $882.32 \pm 72.31$ & $78.11 \pm 10.5$ \\
\hline & 2 & 500 & $52.76 \pm 12.85$ & $76.89 \pm 12.59$ & $55.06 \pm 11.37$ & $75.17 \pm 12.93$ & $875.99 \pm 69.68$ & $79.56 \pm 10.2$ \\
\hline & 3 & 574 & $54.62 \pm 13.13$ & $78.81 \pm 12.45$ & $57.10 \pm 11.80$ & $77.30 \pm 12.05$ & $872.69 \pm 75.14$ & $80.11 \pm 10.65$ \\
\hline & 4 & 505 & $53.14 \pm 12.96$ & $77.43 \pm 12.40$ & $55.59 \pm 11.56$ & $75.63 \pm 12.86$ & $873.39 \pm 80.55$ & $80.13 \pm 11.0$ \\
\hline \multirow{4}{*}{$\mathrm{p}$} & \multicolumn{2}{|c|}{$1-2$} & $>0.05$ & $>0.05$ & $>0.05$ & $>0.05$ & $>0.05$ & $>0.05$ \\
\hline & \multicolumn{2}{|c|}{$2-3$} & $<0.025$ & $<0.025$ & $<0.005$ & $<0.01$ & $>0.05$ & $>0.05$ \\
\hline & & & $<0.005$ & $<0.001$ & $<0.001$ & $<0.001$ & $<0.05$ & $<0.025$ \\
\hline & & & $>0.05$ & $>0.05$ & $<0.05$ & $>0.05$ & $>0.05$ & $>0.05$ \\
\hline
\end{tabular}


Table 2. Changes in physical fitness indices of soldiers in the Land Force of the Lithuanian Armed Forces in different age groups (from 37 to 56 years of age) in the periods of 2010-2011 ( $\bar{x} \pm$ SD)

\begin{tabular}{|c|c|c|c|c|c|c|c|c|}
\hline \multirow{2}{*}{$\begin{array}{l}\text { Age } \\
\text { group }\end{array}$} & \multirow{2}{*}{ Phase } & \multirow{2}{*}{$\mathbf{n}$} & \multicolumn{2}{|c|}{$\begin{array}{l}\text { Hand bending and stretch in } \\
\text { lying position } 2 \mathrm{~min}\end{array}$} & \multicolumn{2}{|c|}{ Sit-ups 2 min } & \multicolumn{2}{|c|}{ Run 3000 m } \\
\hline & & & Result, times & Points & Result, times & Points & Result, s & Points \\
\hline \multirow{4}{*}{$37-41$} & 1 & 264 & $48.51 \pm 12.18$ & $74.55 \pm 12.04$ & $49.05 \pm 11.38$ & $71.38 \pm 11.45$ & $914.32 \pm 76.62$ & $78.00 \pm 10.62$ \\
\hline & 2 & 285 & $48.03 \pm 11.16$ & $74.20 \pm 11.34$ & $49.67 \pm 11.32$ & $72.14 \pm 11.71$ & $909.53 \pm 79.81$ & $78.64 \pm 11.05$ \\
\hline & 3 & 322 & $50.30 \pm 11.72$ & $76.66 \pm 11.62$ & $50.53 \pm 11.62$ & $73.11 \pm 12.12$ & $907.28 \pm 81.87$ & $79.19 \pm 11.23$ \\
\hline & 4 & 346 & $65.21 \pm 11.83$ & $74.79 \pm 11.62$ & $49.85 \pm 11.38$ & $72.38 \pm 11.67$ & $911.34 \pm 79.15$ & $78.50 \pm 11.09$ \\
\hline \multirow{4}{*}{$\mathrm{p}$} & \multicolumn{2}{|c|}{$1-2$} & $>0.05$ & $>0.05$ & $>0.05$ & $>0.05$ & $>0.05$ & $>0.05$ \\
\hline & \multicolumn{2}{|c|}{$2-3$} & $<0.025$ & $<0.01$ & $>0.05$ & $>0.05$ & $>0.05$ & $>0.05$ \\
\hline & \multicolumn{2}{|c|}{$1-3$} & $>0.05$ & $<0.05$ & $>0.05$ & $>0.05$ & $>0.05$ & $>0.05$ \\
\hline & \multicolumn{2}{|c|}{$2-4$} & $>0.05$ & $>0.05$ & $>0.05$ & $>0.05$ & $>0.05$ & $>0.05$ \\
\hline \multirow{4}{*}{$42-46$} & 1 & 107 & $41.71 \pm 10.93$ & $72.84 \pm 11.80$ & $42.03 \pm 10.80$ & $69.92 \pm 10.46$ & $955.42 \pm 84.64$ & $75.64 \pm 10.9$ \\
\hline & 2 & 112 & $42.31 \pm 11.13$ & $73.52 \pm 11.98$ & $42.82 \pm 11.55$ & $70.74 \pm 11.32$ & $945.76 \pm 80.96$ & $77.15 \pm 10.99$ \\
\hline & 3 & 123 & $44.60 \pm 11.60$ & $76.00 \pm 12.50$ & $44.17 \pm 11.59$ & $72.08 \pm 11.33$ & $931.26 \pm 86.69$ & $79.01 \pm 11.6$ \\
\hline & 4 & 120 & $44.30 \pm 11.93$ & $75.51 \pm 12.63$ & $44.15 \pm 11.80$ & $72.03 \pm 16.49$ & $926.62 \pm 86.99$ & $79.71 \pm 11.1$ \\
\hline \multirow{4}{*}{$\mathrm{p}$} & \multicolumn{2}{|c|}{$1-2$} & $>0.05$ & $>0.05$ & $>0.05$ & $>0.05$ & $>0.05$ & $>0.05$ \\
\hline & \multicolumn{2}{|c|}{$2-3$} & $>0.05$ & $>0.05$ & $>0.05$ & $>0.05$ & $>0.05$ & $>0.05$ \\
\hline & \multicolumn{2}{|c|}{$1-3$} & $<0.05$ & $<0.05$ & $>0.05$ & $>0.05$ & $<0.05$ & $<0.05$ \\
\hline & \multicolumn{2}{|c|}{$2-4$} & $>0.05$ & $>0.05$ & $>0.05$ & $>0.05$ & $>0.05$ & $>0.05$ \\
\hline \multirow{4}{*}{$47-51$} & 1 & 31 & $34.13 \pm 10.09$ & $71.32 \pm 10.82$ & $36.64 \pm 7.55$ & $67.29 \pm 8.41$ & $1004.03 \pm 110.15$ & $75.42 \pm 11.68$ \\
\hline & 2 & 25 & $37.60 \pm 10.94$ & $73.80 \pm 9.32$ & $38.72 \pm 6.81$ & $69.60 \pm 7.66$ & $981.36 \pm 103.27$ & $76.14 \pm 12.12$ \\
\hline & 3 & 39 & $33.31 \pm 8.81$ & $70.82 \pm 9.01$ & $37.10 \pm 6.89$ & $67.87 \pm 7.65$ & $1015.10 \pm 109.35$ & $74.31 \pm 12.22$ \\
\hline & 4 & 35 & $35.43 \pm 11.40$ & $72.20 \pm 10.87$ & $37.60 \pm 10.19$ & $68.14 \pm 10.59$ & $982.94 \pm 106.54$ & $77.54 \pm 10.91$ \\
\hline \multirow{4}{*}{$\mathrm{p}$} & \multicolumn{2}{|c|}{$1-2$} & $>0.05$ & $>0.05$ & $>0.05$ & $>0.05$ & $>0.05$ & $>0.05$ \\
\hline & \multicolumn{2}{|c|}{$2-3$} & $>0.05$ & $>0.05$ & $>0.05$ & $>0.05$ & $>0.05$ & $>0.05$ \\
\hline & \multicolumn{2}{|c|}{$1-3$} & $>0.05$ & $>0.05$ & $>0.05$ & $>0.05$ & $>0.05$ & $>0.05$ \\
\hline & \multicolumn{2}{|c|}{$2-4$} & $>0.05$ & $>0.05$ & $>0.05$ & $>0.05$ & $>0.05$ & $>0.05$ \\
\hline \multirow{4}{*}{$32-36$} & 1 & 5 & $28.80 \pm 7.25$ & $67.40 \pm 8.14$ & $29.00 \pm 0.70$ & $61.00 \pm 0.70$ & $1020.20 \pm 100.95$ & $74.60 \pm 13.11$ \\
\hline & 2 & 5 & $23.60 \pm 3.85$ & $63.80 \pm 4.26$ & $30.20 \pm 3.49$ & $62.20 \pm 3.49$ & $1038.60 \pm 87.44$ & $72.20 \pm 11.37$ \\
\hline & 3 & 1 & $30.00 \pm 0.00$ & $71.00 \pm 0.00$ & $30.00 \pm 0.00$ & $62.00 \pm 8.00$ & $1118.80 \pm 0.00$ & $62.00 \pm 0.00$ \\
\hline & 4 & 2 & $27.50 \pm 3.53$ & $68.50 \pm 3.53$ & $29.00 \pm 1.41$ & $61.00 \pm 1.41$ & $1105.00 \pm 21.22$ & $63.50 \pm 20.12$ \\
\hline \multirow{4}{*}{$\mathrm{p}$} & \multicolumn{2}{|c|}{$1-2$} & $>0.05$ & $>0.05$ & $>0.05$ & $>0.05$ & $>0.05$ & $>0.05$ \\
\hline & \multicolumn{2}{|c|}{$2-3$} & $>0.05$ & $>0.05$ & $>0.05$ & $>0.05$ & $>0.05$ & $>0.05$ \\
\hline & $1-$ & & $>0.05$ & $>0.05$ & $>0.05$ & $>0.05$ & $>0.05$ & $>0.05$ \\
\hline & $2-$ & & $>0.05$ & $>0.05$ & $>0.05$ & $>0.05$ & $>0.05$ & $>0.05$ \\
\hline
\end{tabular}

this exercise, and the best results were obtained during the third testing (spring, 2011). The results of this exercise in points for all soldiers during each testing exceeded the minimal norm of 60 points.

The highest indices in aerobic endurance were achieved by 18-21-year-old soldiers. Their $3000 \mathrm{~m}$ running results changed from $787.91 \pm$ $53.15 \mathrm{~s}$ during the first testing to $781.69 \pm 58.26 \mathrm{~s}$ during the fourth testing. In the period of one year (from the first till the third testing), endurance improved statistically significantly for soldiers in the groups of $27-31,32-36$ and $42-46$ years. In each testing, the average evaluation points in all those groups exceeded 80 . Soldiers in all age groups demonstrated higher results for endurance compared to the results in arm bending exercise and sit ups.

Physical fitness of soldiers is evaluated by a sum of points in all APFT exercises. The maximal sum of points is 300 , and the pass is 180 points. Results in all testing periods (Figures 1-8) showed that most points were obtained by soldiers in the 
Figure 1. Physical fitness evaluations in points $(x \pm$ SD) of 18-21 year-old soldiers in the Land Forces in the period of 2010-2011
Figure 2. Physical fitness evaluations in points $(x \pm S D)$ of 22-26 year-old soldiers in the Land Forces in the period of 2010-2011
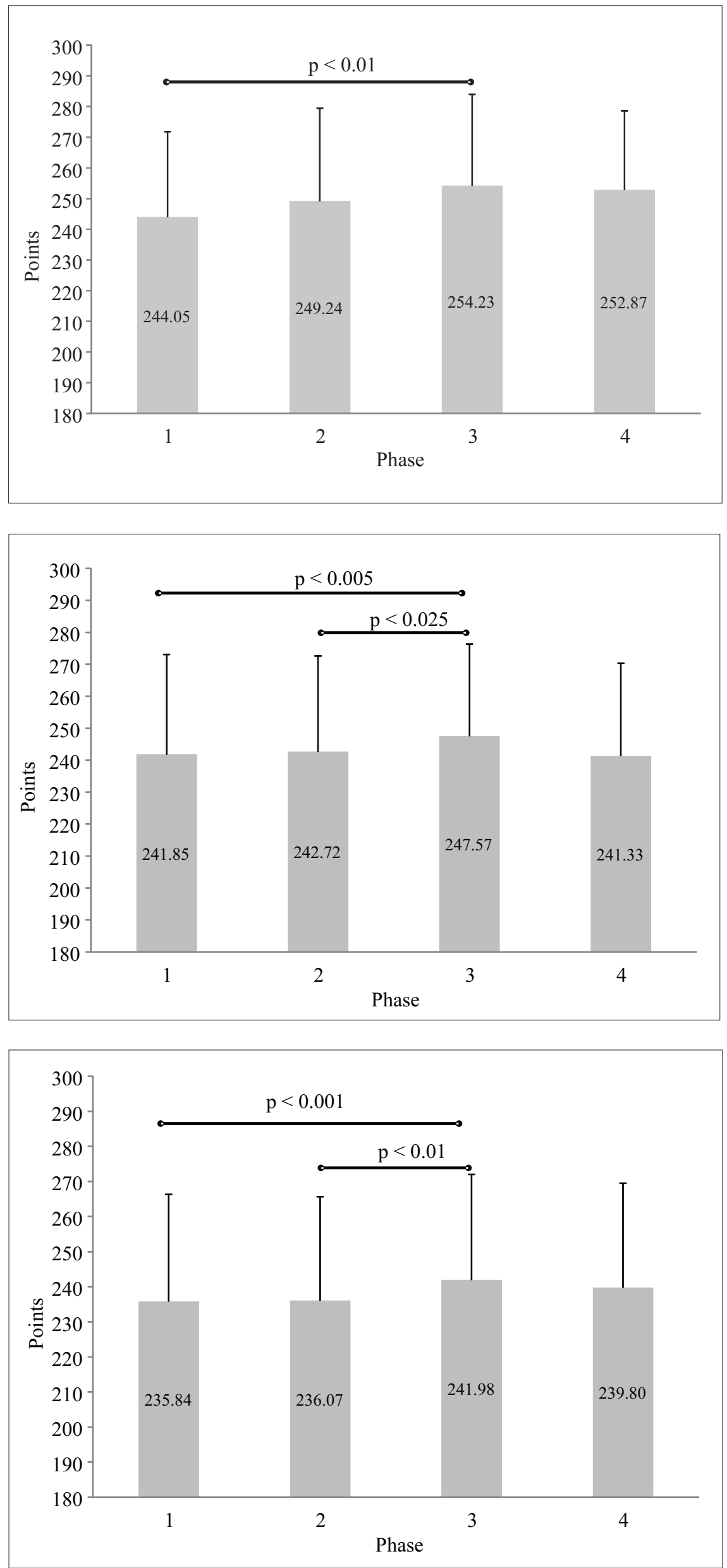

Figure 3. Physical fitness evaluations in points $(x \pm S D)$ of 27-31 year-old soldiers in the Land Forces in the period of 2010-2011 

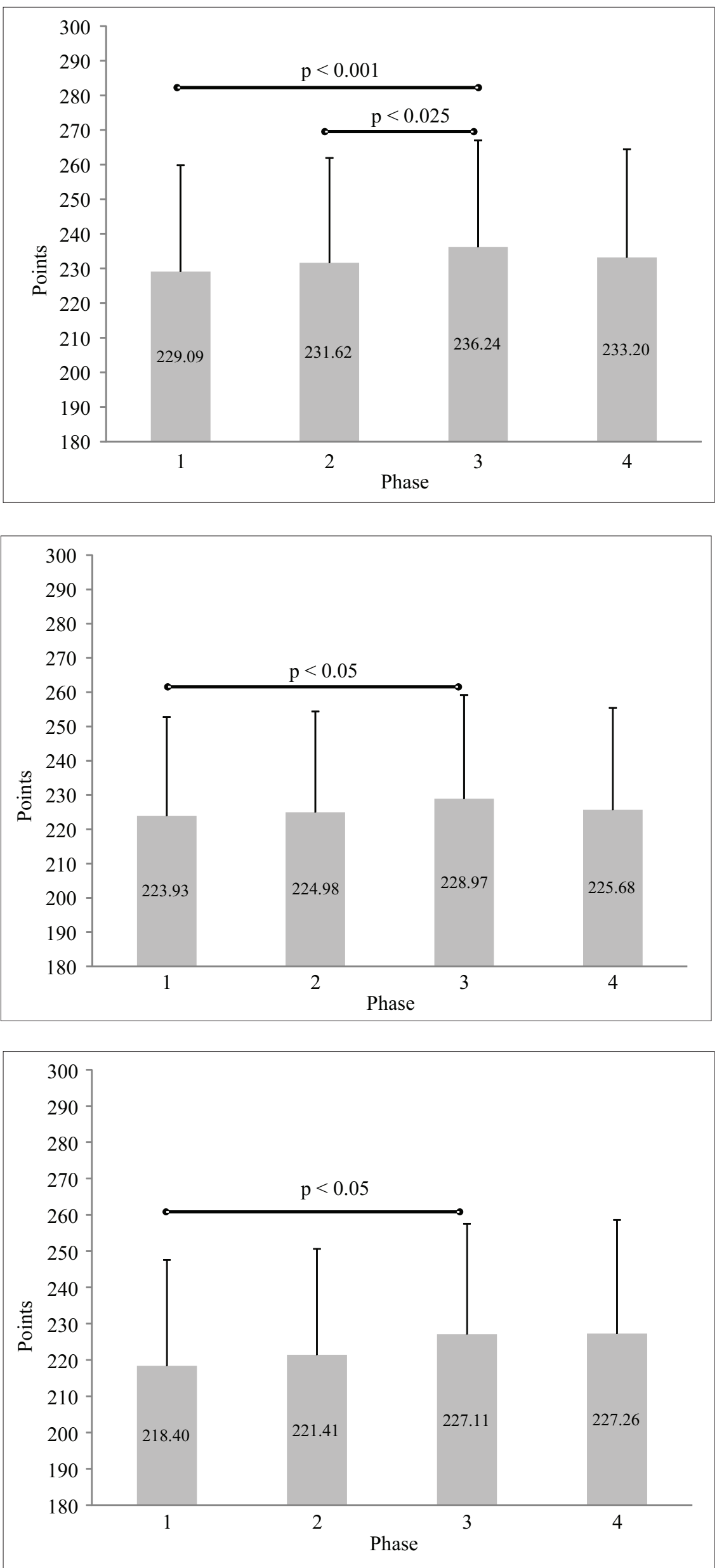

Figure 4. Physical fitness evaluations in points $(x \pm S D)$ of 32-36 year-old soldiers in the Land Forces in the period of 2010-2011

Figure 5. Physical fitness evaluations in points $(x \pm$ SD) of 37-41 year-old soldiers in the Land Forces in the period of 2010-2011

Figure 6. Physical fitness evaluations in points $(x \pm S D)$ of 42-46 year-old soldiers in the Land Forces in the period of 2010-2011 
Figure 7. Physical fitness evaluations in points $(x \pm S D)$ of 47-51 year-old soldiers in the Land Forces in the period of 2010-2011

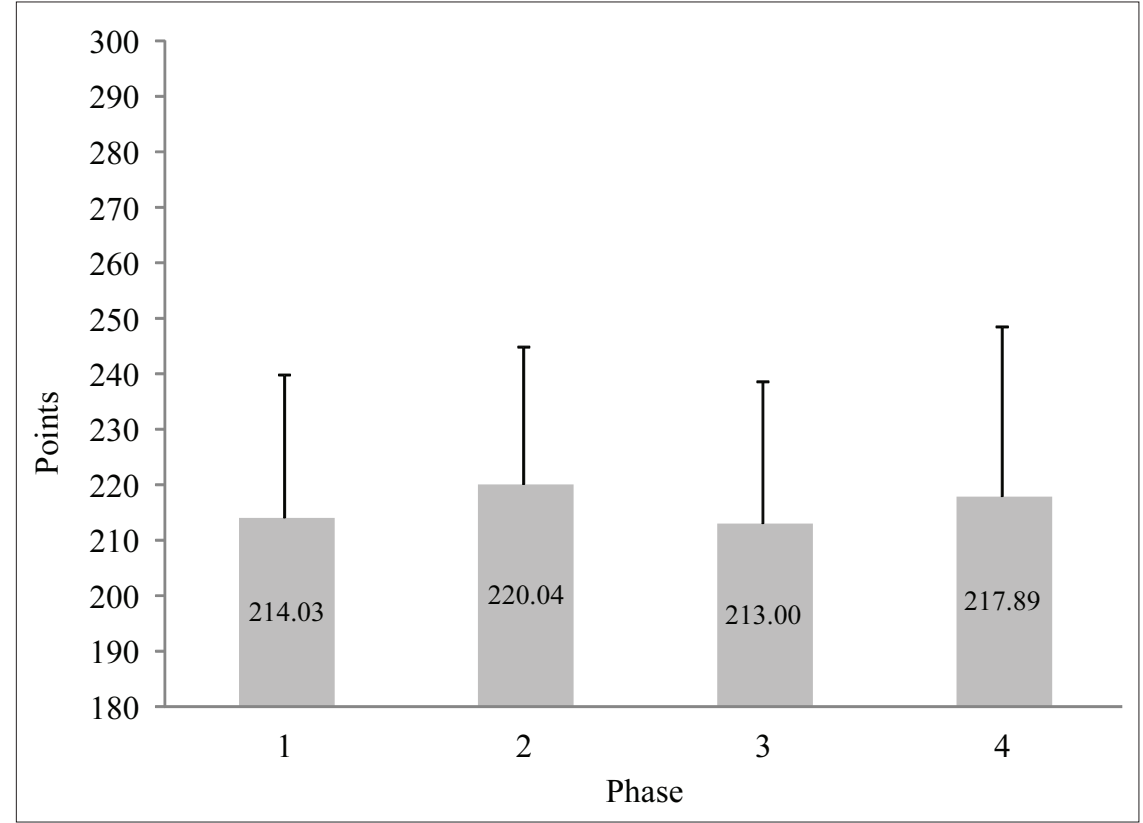

Figure 8. Physical fitness evaluations in points $(x \pm S D)$ of 52-56 year-old soldiers in the Land Forces in the period of 2010-2011

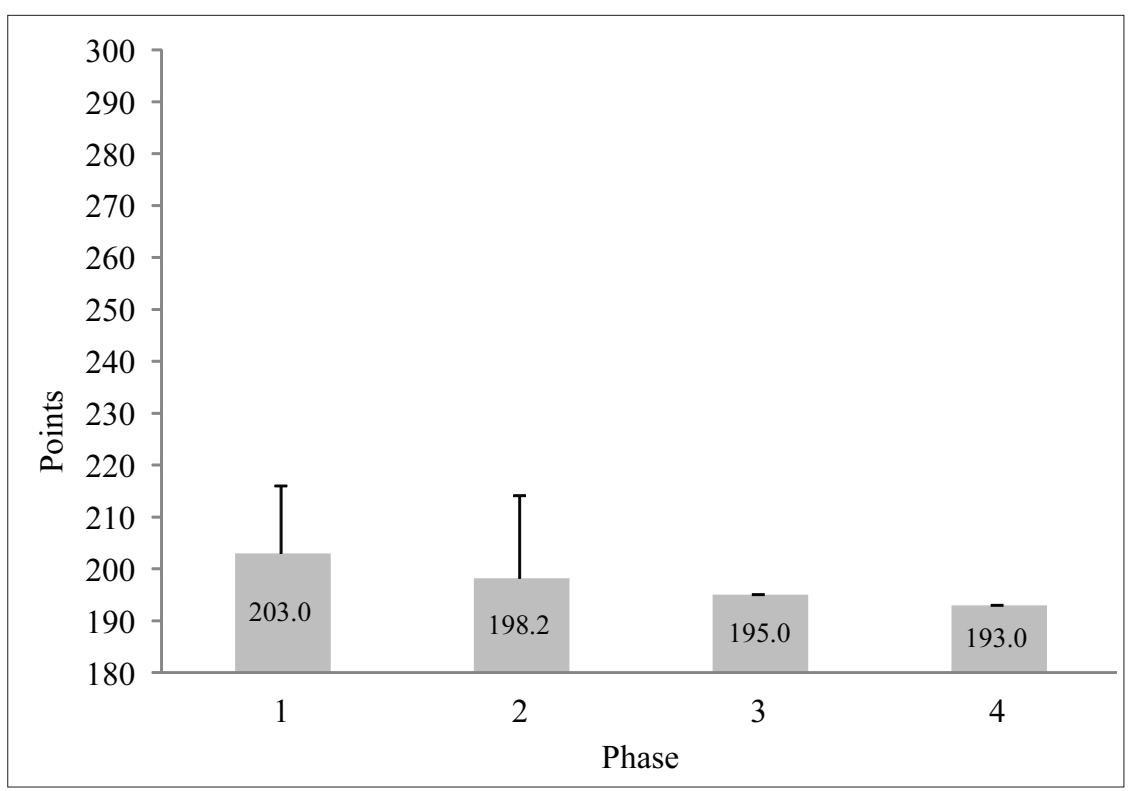

groups of 18-21, 22-26 and 27-31 years. Their sums of points in all APFT exercises ranged from 235 to 254 points. In the period of one year, from the first to the third testing, complex physical fitness improved in six groups: 18-21 years $(\mathrm{p}<0.01), 22-26(\mathrm{p}<0.005), 27-31$ years ( $\mathrm{p}<0.001), 32-36$ years $(\mathrm{p}<0.001), 37-41$ years $(\mathrm{p}<0.05)$, and $42-46$ years $(\mathrm{p}<0.05)$. In the period of half a year, from spring to autumn and from autumn to spring, soldiers' physical fitness changed only slightly $(\mathrm{p}>0.05)$. APFT data (Table 3) in the Land Force suggest that $81-86 \%$ of soldiers passed the standard norms, $2-3 \%$ of soldiers failed the norms, and $12-16 \%$ did not take tests at all because they carried out some other military tasks or fulfilled some mission.

Table 3. Physical fitness testing results of soldiers in the Land Force of the Professional Lithuanian Armed Forces

\begin{tabular}{|c|c|c|c|}
\hline $\begin{array}{c}\text { Research } \\
\text { phases }\end{array}$ & $\begin{array}{c}\text { Passed, } \\
\text { \% }\end{array}$ & Failed, \% & $\begin{array}{c}\text { Did not } \\
\text { participate } \\
\text { in testing, \% }\end{array}$ \\
\hline 1 & 84 & 3 & 13 \\
\hline 2 & 81 & 3 & 16 \\
\hline 3 & 86 & 2 & 12 \\
\hline 4 & 82 & 4 & 14 \\
\hline
\end{tabular}




\section{DISCUSSION}

Military physical fitness is the ability of a soldier to carry out military tasks efficiently, tolerate physical loads in their service or military training, deal with physical and mental tension under the pressure of various factors (Kariu fizinio rengimo metodinès rekomendacijos, 2003). Soldiers' physical fitness must match specific aims and objectives of a military unit. Irrespective of their military rank, age and position, all soldiers must maintain optimal level of physical fitness. Physical fitness testing carried out in Lithuanian Armed Forces twice a year stimulates soldiers to develop their physical skills systematically.

The armed forces of other NATO states pay much attention to physical fitness control, and physical fitness results are analyzed according to the age groups as in the Lithuanian Armed Forces (Dobosz, Świersz, 2011; Dybińska, 2009, 2011; Kruczkowski et al., 2011).

Abdominal muscle endurance indices of soldiers in the Lithuanian Professional Land Force (sit ups test $2 \mathrm{~min}$ ) in all age groups were better compared to those of soldiers in Professional Polish Armed Forces (Kruczkovski et al., 2011). The authors' research (Kruczkovski et al., 2011) provides the following data of sit ups test in Professional Polish Armed Forces: for soldiers younger than 29 years of age $(\mathrm{n}=49)-56.61 \pm 11.98$ times, $30-34$ years $(\mathrm{n}=108)-53.95 \pm 7.09$ times, $35-39$ years $(\mathrm{n}=117)-48.82 \pm 6.35$ times, $40-44$ years $(\mathrm{n}=80)-43.98 \pm 6.34$ times, and $45-49$ years $(\mathrm{n}=17)-42.41 \pm 8.46$ times.

Arm strength endurance indices (bending and reaching arms in a lying position for $2 \mathrm{~min}$ ) of soldiers in the Lithuanian Professional Land Force in the age groups of 27-31, 32-36, 37-41 and 42-46 years were higher than the same indices of soldiers in Professional Polish Armed Forces, as provided in the research publication by E. Dybińska (2011). Arm strength endurance indices of soldiers in Professional Polish Armed Forces were as follows: $26-30$ years $(\mathrm{n}=96)-47.66 \pm 4.0$ times, $31-35$ years $(\mathrm{n}=91)-47.58 \pm 4.83$ times, $36-45$ years $(\mathrm{n}=86)-40.72 \pm 4.45$ times (Dybińska, 2011).

Aerobic endurance indices (3000 m running) of soldiers in the Lithuanian Professional Land Force and the ones of soldiers in Professional Polish Armed Forces (Kruczkovski et al., 2011) did not differ significantly. Aerobic endurance indices of soldiers in Professional Polish Armed Forces according to the testing results of 2009 (Kruczkovski et al., 2011) were as follows: for soldiers younger than 29 years $(\mathrm{n}=45)-13.81 \pm 1.02,30-34$ years $(\mathrm{n}=88)-14.24 \pm$ $2.07,35-39$ years $(\mathrm{n}=100)-14.07 \pm 2.49,40-44$ years $(\mathrm{n}=65)-15.27 \pm 2.00,45-49$ years $(\mathrm{n}=11)-$ $17.12 \pm 4.57$.

We compared physical fitness indices of soldiers in the Lithuanian Professional Land Force with the ones of soldiers in the mandatory conscription service of the Lithuanian 160th Motorized Infantry Brigade Honor Guard in 2001 and 2003 (Radžiukynas et al., 2006). Abdominal muscle strength indices (sit ups for $2 \mathrm{~min}$ ) of our research participants aged 18-21 and 22-26 years were higher compared to those of the Motorized Infantry Brigade Honor Guard soldiers in 2001 and 2003, but the arm strength indices (press ups for $20 \mathrm{~min}$ ) were higher for soldiers in the Motorized Infantry Brigade Honor Guard. Aerobic endurance indices (3000 m running) of our research participants aged 18-21 and 22-26 years were similar to those of the Motorized Infantry Brigade Honor Guard soldiers.

Physical fitness of soldiers in the Land Force of the Lithuanian Armed Forces matches the normative requirements approved by the Lithuanian Minister of National Defense. Physical fitness indices did not change much in the period of half a year (from spring testing till autumn testing), but in some age groups they tended to decline. From 37 years of age physical fitness indices were worse compared to those of younger soldiers. For this reason it is necessary to encourage soldiers to participate in recreational physical activities and to increase their individual physical activity independently.

\section{CONCLUSIONS AND PERSPECTIVES}

1. Physical fitness indices of different exercise for soldiers in the Land Force of the professional Lithuanian Armed Forces who passed that APFT test were higher than the established minimal normative requirements. During each testing, $12-16$ percent of soldiers did not participate in testing procedures as they carried out other military official tasks or could not participate due to their poor health, and 2-4 percent failed the APFT tests.

2. Physical fitness indices of soldiers improved during a period of one year - between testing in spring, testing I and testing III. In the period of half a year (from spring to autumn), no significant differences in the changes of physical fitness indices were established $(\mathrm{p}>0.05)$. 
3. The highest physical fitness indices were achieved in the age groups of 18-21, 22-26, 27-31 and 30-36 years, however, the differences between the age groups were insignificant. The indices of soldiers in the age group of 37-41 and older were worse compared to those for younger soldiers in the age groups mentioned above.
In perspective, while developing military physical fitness control system, the testing programme should be supplemented with tests for psychomotor abilities, and the evaluation of physical fitness should be differentiated according to the normative scale which includes such evaluations as "excellent", "good", "fair".

\section{REFERENCES}

Dobosz, J. Świercz, M. (2011). Physical fitness of soldiers from land forces units in 2009 and 2010 years. In M. Sokołowski (Ed.), A Diagnosis of Physical Fitness in the Contemporary Army (pp. 39-61). Warszawa: Polish Scientific Physical Education Association Section of Physical Education in the Army.

Dybińska, E. (2009). Physical fitness of regular soldiers from Rzeszów Military Distric in 2006-2008. In M. Sokołowski (Ed.), Contemporary Tasks, Problems and Perspectives of Physical Education in the Army (pp. 13-22). Warszawa: Polish Scientific Physical Education Association Section of Physical Education in the Army.

Dybińska, E. (2011). Physical fitness of professional soldiers from Resovia district in years 2008, 2009 to specific age groups. In M. Sokołowski (Ed.), $A$ Diagnosis of Physical Fitness in the Contemporary Army (pp. 63-77). Warszawa: Polish Scientific Physical Education Association Section of Physical Education in the Army.

Dyrstad, Sinche-M., Soltvedt, R., Hallén, J. (2006). Physical fitness and physical training during Norwegian military service. Military Medicine, 171 (8), 736-741.

Faff, J., Satara, P., Stasiak, K. (2002). Changes in aerobic and anaerobic capacities of Army recruits during their military training are related to the initial level of physical fitness of the subjects. Biology of Sport, 19 (3), 251-265.

Górski, P. (2007). Compensatory training programs for regular cadre of the Polish army. In M. Sokołowski (Ed.), Biosocial Effects of Military Service as a Basis for Further Improvement of Future Physical Education and Sports Programmes (pp. 277-284). Poznan: Poznán Academia Wychowania fizyczniego im. Piaseckiego w Poznaniu.

Greičius, R., Tutkus, E., Skrebe, B., Kočiukaitis, V. (1998). Lietuvos kariuomenès kariu fizinis rengimas [CD-ROM]. Vilnius.

Ivaškienė, V. (2010). Skirtingo šaukimo pradinès privalomosios karo tarnybos karių iš kaimo ir miesto fizinio parengtumo ypatumai. Sportini darbinguma lemiantys veiksniai (III): moksliniu straipsniu rinkinys (el. versija) (pp. 152-159)). Kaunas: Lietuvos kūno kultūros akademija.

Janowski, J., Strzelczyk, R., Karpowicz, K., Konarski, J. (2009). Physical fitness of soldiers from armoured and reconnaissance unites in view of selected socio-cultural factors. In M. Sokołowski (Ed.), Contemporary Tasks, Problems and Perspectives of Physical Education in the Army (pp. 23-31). Warszawa: Polish Scientific Physical Education Association section of Physical Education in the Army.

Kariu fizinio rengimo metodinès rekomendacijos. (2003). Parengė R. Greičius, E. Tutkus, V. Kočiubaitis. Kaunas: Karo medicinos tarnyba.

Kruczkowski, D., Jaszczur-Nowicki, J., Granda, T. (2011). Manifestation of physical fitness in professional Navy Soldiers in the aspect of Polish Army professionalization. In M. Sokołowski (Ed.), A Diagnosis of Physical Fitness in the Contemporary Army (pp. 107125). Warszawa: Polish scientific physical education association section of physical education in the army.

Lietuvos gynybos politikos baltoji knyga. (2006). Ats. red. K. Paulauskas. Vilnius: Lietuvos Respublikos krašto apsaugos ministerija, Leidybos informacinio aprūpinimo tarnyba.

Młynarczyk, C., Dorsz, A., Smorawiński, J. (2007). Training intensity and physical capacity of soldiers. In M. Sokołowski (Ed.), Biosocial Effects of Military Service as a Basis for Further Improvement of Future Physical Education and Sports Programmes (pp. 113117). Poznań: AWF.

Physical Fitness Training. FM 21-20. (1992). Washington: Headquarters Department of the Army.

Radžiukynas, D., Endrijaitis, R. (2003). Generolo Jono Žemaičio Lietuvos karo akademijos pirmo kurso kariūnų fizinio rengimo ypatumai. Ugdymas. Kūno kultūra. Sportas, 5 (50), 8-14.

Radžiukynas, D. (1999). Lietuvos karo akademijos kariūnu fizinis ugdymas pirmais studiju metais: daktaro disertacija Vilnius: Pedagoginis universitetas.

Radžiukynas, D., Sakalys, V., Godliauskas, M. (2006). Privalomosios karo tarnybos karių fizinio ugdymo ypatumai. Sporto mokslas, 2 (44), 61-67.

Savonis, A., Čepulenas, A. (2011). Physical fitness of the Lithuanian military training troop soldiers. In M. Sokołowski (Ed.), A Diagnosis of Physical Fitness in the Contemporary Army (pp. 193-202). Warszawa: Polish Scientific Physical Education Association Section of Physical Education in the Army.

Savonis, A., Čepulènas, A. (2012). Physical training of candidates to professional military service in Lithuanian armed forces. Ugdymas. Kūno kultūra. Sportas, 3 (86), 87-92. 
Sipavičius, S., Ramanauskienè, I., Skurvydas, A. et al. (2008). Kariūnų organizmo atsakas atliekant žygi aukštoje aplinkos temperatūroje. Kūno kultūra ir sportas universitete: tarptautinès konferencijos medžiaga (pp. 100-102).

Sokołowski, M. (2002). Wychowanie fizyczne i sport w procesie prsygotowania Zawodowego w wojsku. In M. Sokołowski (Ed.), Kultura fizyczna $w$ wojsku $w$ dobie przemian (pp. 324-328). Poznań: Wydawnictwo Wyzszej Szkoly Oficierskiej im Stefana Czarnieckiego.

Streckis, V., Endrijaitis, R., Krasauskas, A., Mamkus, G. (2004). Lietuvos karo akademijos pirmo kurso studentu raumenų galingumo, jègos ir greitumo ypatybiu kaita. Ugdymas. Küno kultūra. Sportas, 4 (54), 85-88.

Trinkūnas, E. (2009). Skirtingo šaukimo karių fizinio pasirengimo kaita bazinio kurso metu. Sportini darbinguma lemiantys veiksniai (II): moksliniu straipsniu rinkinys (el. versija) (pp. 164-173). Kaunas: Lietuvos kūno kultūros akademija.

Vilkas, A., Kepežènas, A., Radžiukynas, D. (1994). Lietuvos kariuomenès karių, pašauktų 1993 m. pavasari, fizinio išsivystymo, fizinio parengimo ir organizmo funkcinių galimybių tyrimo duomenys. Ivairaus amžiaus gyventoju fizinio aktyvumo, fizinio ugdymo ir sveikatos problemos (pp. 119-122). Vilnius.

Witkowski, K., Stefaniak, T., Majsnerowski, M. (2007). Physical fitness of soldiers in the regular or professional military service in the NATO response task force. In M. Sokołowski (Ed.), Biosocial Effects of Military Service as a Basis for Further Improvement of Future Physical Education and Sports Programmes (pp. 145153). Poznań: Akademia Wychowania Fizycznego im. E. Piaseckiego w Poznaniu.

\title{
LIETUVOS PROFESIONALIOSIOS KARIUOMENĖS SAUSUMOS PAJĖGŲ IVAIRAUS AMŽIAUS GRUPIŲ KARIŲ FIZINIO PARENGTUMO REZULTATAI PER 2010-2011 METUS
}

\author{
Aurelijus Savonis ${ }^{1,2}$, Algirdas Čepulènas ${ }^{2}$ \\ Divizijos generolo Stasio Raštikio Lietuvos kariuomenès mokykla ${ }^{1}$, Kaunas, Lietuva \\ Lietuvos sporto universitetas ${ }^{2}$, Kaunas, Lietuva
}

\section{SANTRAUKA}

Tyrimo pagrindimas ir hipotezé. Nuo $2009 \mathrm{~m}$. Lietuvos kariuomenė formuojama tik iš profesionaliosios karo tarnybos karių. Mokslo darbų, nagrinėjančiu Lietuvos profesionaliosios karo tarnybos karių fizini parengtumą ir jo kaitos ypatumus tarnybos laikotarpiu, nepakanka. Šiuo tyrimu siekiama patikrinti hipotezę, kad profesionaliosios karo tarnybos karių fizinis parengtumas atitinka krašto apsaugos ministro patvirtintus fizinio parengtumo normatyvus.

Tikslas - ištirti Lietuvos profesionaliosios kariuomenès sausumos pajėgų i̇vairaus amžiaus grupių karių fizinio parengtumo kaitos ypatumus per dvejus metus.

Metodai: literatūros šaltiniu studija, fizinio parengtumo testavimas, fizinio parengtumo rodiklių statistinè analizè. Kiekvieno fizinio pratimo rezultatas buvo vertinamas taškais pagal karių fizinio parengtumo normatyvines skales. Taškų suma už visus atliktus fizinius pratimus - galutinis fizinio parengtumo rezultatas.

Rezultatai. Visų amžiaus grupių kariu fizinio parengtumo rodikliai nuo testavimo pavasarị iki testavimo rudeni pakito mažai $(\mathrm{p}>0,05)$. Per vienų metų laikotarpi (nuo testavimo pavasari iki kitų metų testavimo pavasarị) kariu fizinio parengtumo rodikliai pagerẻjo $(\mathrm{p}<0,05)$. Fizinio parengtumo normatyvų neišlaikè $2-4 \%$ kariu.

Aptarimas ir išvados. Sausumos pajęgu profesionaliosios tarnybos karių, išlaikiusių fizinio parengtumo testą, fizinio parengtumo rodikliai pagal atskirus pratimus yra geresni už nustatytus minimalius iskaitinius normatyvus. Geriausius fizinio parengtumo rodiklius pasiekia 18-21, 22-26, 27-31, 32-36 metu grupių kariai, tačiau rodikliu skirtumai tarp amžiaus grupių karių maži.

Tobulinant karių fizinio parengtumo kontrolès sistemą reikètų fizini parengtumą vertinti diferencijuotai pagal ivertinimu ,puikiai“, ,gerai“, „pakankamai“ normatyvinę skalę. taškai.

Raktažodžiai: sausumos pajėgos, fizinis parengtumas, testavimas, fizinio parengtumo testas, amžiaus grupės,

Gauta 2013 m. sausio $27 \mathrm{~d}$.

Received on January 27, 2013

Priimta 2013 m. kovo $8 \mathrm{~d}$.

Accepted on March 8, 2013
Corresponding author Aurelijus Savonis

Division General Stasys Raštikis Lithuanian Armed Forces School Physical Training Center

S. Darius and S. Girènas str. 100, LT-46263 Kaunas Lithuania

Tel +37069809329

E-mail aurelijus.savonis@gmail.com 